\title{
The political sciences of European integration: disciplinary history and EU studies
}

\author{
Ben Rosamond
}

Department of Politics and International Studies

University of Warwick

Coventry CV4 7AL

United Kingdom

b.j.rosamond@warwick.ac.uk

http://www2.warwick.ac.uk/fac/soc/pais/

Paper presented to the tenth biennial conference of the European Union Studies Association (EUSA), Montreal, 17-19 May 2007 


\section{The political sciences of European integration: disciplinary history and EU studies}

\section{Ben Rosamond}

\section{Introduction}

The task of writing disciplinary history is far from straightforward. ${ }^{1}$ Like all history, the composition of a narrative about a field is undertaken at a particular time and in a particular place - from a particular 'subject position' that may reflect certain biases which in turn follow from a multiplicity of concerns that follow from those temporal and spatial coordinates. 'Formal' disciplinary histories in any field are relatively rare, while stock-taking, 'state of the art' exegeses are found rather more often. More common still, though largely unacknowledged as exercises in disciplinary history, are those acts of framing and story-telling about a field's past that routinely pepper scholarship in an area of enquiry. In other words scholarly activity is characterised by the constant flow of stories, which offer claims about routes to progress through the rectification of past errors and classify the field's development over time. Thus interventions in a field's present routinely make arguments about that field's past. The net result could well be that the history of a field is known more by reputation than readership' (Fuller, 2003: 29).

The most prominent recent historian of the discipline of international relations (IR) argues that there 'is an intimate link between disciplinary identity and the manner in which we understand the history of the field' (Schmidt, 2002: 16). If regular interventions in a field of enquiry habitually offer constructions of the field's past in order to justify intellectual moves made in the present, then critical engagement with disciplinary history also - by definition - shines an inquisitive torchlight on the disciplinary present. The task of such work is to interrogate 'the retrospective teleology of discipline-history' (Collini, Winch and Burrow, 1983: 7). If this is not done then

\footnotetext{
${ }^{1}$ This paper has been published as chapter 1 of Knud Erik Jørgensen, Mark A. Pollack and Ben Rosamond (eds) Handbook of European Union Politics, London: Sage, 2007, pp. 7-30
} 
[t]he present theoretical consensus of the discipline, or possibly some polemical version of what that consensus should be, is in effect taken as definitive, and the past is then reconstituted as a teleology leading up to and fully manifested in it. (Collini, Winch and Burrow, 1983: 4)

This chapter does not pretend to offer a single definitive account of the field of EU politics, but it does investigate the various formal and informal accounts that exist in terms of the above observations. It begins with two short preparatory discussions. The first identifies six issues that intercept any attempt to write disciplinary history in this area, while the second supplies a rough 'anatomy' of the field of EU studies/EU politics in an effort to adjudicate some fundamental issues surrounding the substance of this area of study. In so doing, it perhaps justifies this chapter's focus on what appears to be an Anglophone academic mainstream. It then moves to describing and offering critical engagement with standard accounts of the field with a view to showing how, overwhelmingly, extant stories about the evolution of EU studies are bound up with particular claims about the organisation of knowledge in the present. Indeed the argument here suggests that disciplinary history is used to adjudicate disputes about the proper scope and substance of the study of EU politics, which in turn connect to some quite fundamental struggles for the soul of political science.

Thus the chapter is also attentive to sociology of knowledge questions. These remind us that our knowledge about the world is produced amidst broad scientific and more specific disciplinary structures, norms, practices and institutions - what Jørgensen (2000) neatly calls the 'cultural-institutional context' of academic work. It follows that the evolution of a field is (at the very least) partly a function of developments within the field. These in turn might reflect much broader path dependent pathologies, which take us back to the intellectual and socio-political conditions of disciplinary foundation (Mancias, 1987). This 'internalist' take on disciplinary history might not necessarily provide a full explanation of why scholars of EU politics address particular puzzles at particular moment, but it does offer a framework for understanding why particular theories and approaches dominate at particular times (Schmidt, 1998; Wæver, 2003). At the same time, many would prefer to argue for an 'externalist' understanding of disciplinary evolution, where the main academic 
innovations are largely construed as responses to the changing anatomy of the field's primary object of study (the EU/the politics of European integration).

\section{The study of EU politics: six perennial issues}

The field of EU studies, or for the purposes of this volume, the study of 'EU politics', brings with it some particular local complications. These issues render problematic any attempt to establish what Wessels calls the 'acquis academique' (2006: 233), let alone trace its evolution.

First, it does not necessarily follow that 'EU politics' and 'the political science of the EU' are synonymous. 'Political science' may connote a set of techniques for study of political phenomena and there are those who argue that the most 'progress' has been made in EU studies at those points where the intellectual technologies most associated with mainstream political science have been applied most rigorously. But it might be that the fullest picture of EU politics is obtained through the collective and sometimes collaborative efforts of several disciplinary communities.

Second, we are then led into some complex arguments about disciplines, subdisciplines and disciplinary/subdisciplinary boundaries. Within political science (broadly defined), we find a co-existing array of modes of enquiry, which often organise themselves into coherent fields such as public administration, policy analysis and political economy - each of which may by prefixed by 'comparative' or 'international'. Scholars of politics tend to auto-define themselves in terms of these sub-tribes, whilst retaining an overall affiliation to the label 'political scientist', although a dividing line is often drawn between IR and political science - not least in a good deal of the EU studies literature.

A third related point grows out of the question of disciplines and disciplinarity. Is EU studies a branch of (a particular) social science or is it a form of 'area studies'? It might also presuppose a clear stance on the status of alternative forms of knowledge generation: 'deductive' versus 'inductive', 'nomothetic' versus 'idiographic' and so on (Lustick, 1997; Jupille, 2006; Wallace, 2000: 96; see also Calhoun, 2003). 
Fourth, is territoriality a key variable? On the face of it, the intellectual community of EU studies is multi-national and polyglot as well as being multi-disciplinary. Are there distinct inter-national or inter-regional cleavages in how the EU has been and is studied? Obviously, we might expect scholars from different parts of the world to bring 'local' (empirical or social scientific) preoccupations to the study of the EU. For example, is there a distinctively British/continental/European approach to the study of the EU and does it contrast with an American/US variant? Do these produce distinctive readings of EU politics? How embedded are these national or regional approaches? Do national/regional social scientific traditions and institutional constellations prevail as determinants of how EU politics is studied in particular places? Or has EU studies gradually converged or globalized (perhaps Americanized?) around a set of core propositions, puzzles and forms of knowledge production?

Fifth, there is the deceptively simple question: when did EU studies begin? The rather obvious response is to insist that a defined field of study begins when its object of study (the EU and its antecedents) is founded (1951 in the case of the ECSC). But, of course, fields of study can never have a precise 'year zero' in that the study of any social scientific object will draw upon both long standing and ephemeral intellectual resources. Thus as Follesdal notes in this volume (chapter 16), the normative case for a European federation pre-dates post-World War II institutional forms by at least two centuries. If the Communities are read as solutions to the problem of war, then the emergent discipline of IR had been dealing with such questions for decades (though see Schmidt, 1998; Smith, 2003). Moreover, if we think more broadly and historically about European integration, then the EU can be read as but a recent institutional expression of some very long-standing and long studied historical processes (Wallace, 2002).

Finally, there is one further quite distinctive issue, namely the extent to which the EU itself has been integral to the promotion of the discipline(s) that seek to analyse it. The Commission's Jean Monnet Project (Action Jean Monnet) is well known as a major benefactor of teaching and research in European integration studies within Europe. The project's database lists a cumulative total of 2477 Monnet chairs, permanent courses, modules and centres of excellence, of which 509 are designated as falling 
within the remit of 'European political science'. ${ }^{2}$ As well as further support for the creation of transnational research groups, the Commission contributes funds towards five major institutions across the continent: The College of Europe (campuses in Bruges - founded 1949 - and Natolin, Warsaw - 1992), The European University Institute (Florence, founded 1975), the European Institute of Public Administration (Maastricht, 1981), the Academy of European Law (Europäische Rechtsackadamie, Trier, 1992) and the International Centre for European Training (Centre international de formation européenne, Nice, 1954). More recently, the Commission's sixth framework programme made a particular point of ring fencing monies for the creation of European academic networks to study citizenship and governance issues. The Commission has also been a major funder of EU-related scholarship in the United States. Ten EU Centers (EUCs - made up of individual universities or consortia of geographically adjacent institutions) were created in 1998 with funding averaging $\$ 500,000$ per centre for three years. A total of 15 EUCs have received funding (Keeler, 2005). ${ }^{3}$

Any attempt to make an argument about the history of EU studies or the study of EU politics needs to grapple with these questions. It is also true that each of the six problems introduced above represent ongoing controversies within the field. The contention here is that a crucial part of the history of EU studies, particularly within the last decade, has been about alternative representations of the history of the field and that these alternative representations bring with them consequences.

\section{The anatomy of a field}

As noted above, the study of EU politics might be organised in a number of ways. Two stylized alternatives spring to mind. In the first, the study of EU politics would be the domain of political scientists, while lawyers would produce scholarship on

\footnotetext{
${ }^{2}$ http://europa.eu.int/comm/dg10/university/ajm/dbajmon.html - accessed 9 March 2006.

${ }^{3}$ It is difficult to measure the impact of these funding efforts, particularly since we have no way of establishing 'value added' indices (i.e. would research output have differed significantly without Commission seed funding?). That said, John Keeler's data point to the fact that EUCs were consistently responsible for the highest numbers of doctoral dissertations produced on EU topics between 1990 and 2001 (Keeler, 2005: 566, fn 23). It is important to recognise that the Commission has not been the sole source of funding for EU studies programmes in the United States. The US Department of Education's 'Title VI' (National Resource Centers) programme and the German Academic Exchange Service (DAAD) have also been important funding sources. Keeler shows that only one externally funded centre existed in the US in 1976, whereas 30 were being underwritten by the major grant awarding organizations in 2001 (Keeler, 2005: 565).
} 
European law, economists would focus on the EU economy and so on. At the other pole sits the claim that the study of EU politics should be an inherently multi(perhaps inter-) disciplinary affair.

\section{Academic associations}

One way to provide a snapshot of the disciplinary composition of EU studies involves examining the membership data provided by those organisations which explicitly purport to organise scholarship in the field. EU studies is most obviously organised through a network of European Community Studies Associations (ECSAs). Tables 1 and 2 are derived from information supplied by the overarching ECSA organisation. ${ }^{4}$ Table 1 simply ranks the world's 10 largest ECSAs and reproduces information on the proportion of the membership that is designated as 'political science'. Table 2 (again straightforwardly) lists the half dozen ECSAs where the 'political science' membership is said to be greater than or equal to 50 per cent. It is worth noting that there are no fewer than 52 formally constituted ECSAs, suggesting that barely 10 per cent can claim a majority 'political science' membership.

Table 1: Largest ECSAs

\begin{tabular}{|c|l|c|c|}
\hline & \multicolumn{1}{|c|}{ Country (Association) } & Membership & $\begin{array}{c}\text { \% of membership } \\
\text { 'political science' }\end{array}$ \\
\hline 1 & United States (EUSA) & 1600 & 78 \\
\hline 2 & United Kingdom (UACES) & 1000 & 50 \\
\hline 3 & Japan (EUSA Japan) & 487 & 30 \\
\hline 4 & Germany (AEI) & 438 & 30 \\
\hline 5 & France (CEDECE) & 410 & 20 \\
\hline 6 & Italy (AUSE) & 300 & 18 \\
\hline 7 & China (CSEUS) & 256 & 32 \\
\hline 8 & Russia (AES Russia) & 230 & 26 \\
\hline 9 & Taiwan (EUSA-Taiwan) & 207 & 20 \\
\hline 10 & Rep of Korea (ECSA & 200 & 3 \\
\hline
\end{tabular}

Source: http://www.ecsanet.org (accessed 7 February 2006)

\footnotetext{
${ }^{4}$ The precision of some of these statistics is questionable. At best many seem to be estimates that do not necessarily correspond to membership data available from national ECSAs themselves. I present them here on the assumption that they more or less accurately reflect the broad compositional pattern of EU studies worldwide.
} 
Table 2: ECSAs with at least 50 per cent of membership identified as 'political science'

\begin{tabular}{|l|c|c|}
\hline \multicolumn{1}{|c|}{ Country (Association) } & $\begin{array}{c}\text { \% of membership 'political } \\
\text { science' }\end{array}$ & Membership \\
\hline United States (EUSA) & 78 & 1600 \\
\hline Norway (NFEF) & 75 & 56 \\
\hline Denmark (DSE) & 60 & 100 \\
\hline $\begin{array}{l}\text { United Kingdom } \\
\text { (UACES) }\end{array}$ & 50 & 1000 \\
\hline Canada (ECSA-C) & 50 & 150 \\
\hline Hong Kong (HKMAES) & 50 & 110 \\
\hline
\end{tabular}

Source: http://www.ecsanet.org (accessed 7 February 2006)

Yet, the total global ECSA membership (excluding associations for which there is incomplete data) is 6896, of whom 2957 are identified as 'political science' (43 per cent). Of these, 1748 are members of just two national associations (EUSA, US and UACES, UK), suggesting that some 59 per cent of the EU studies political science community is based in (or at least affiliated to) the two main Anglophone academic communities (42 per cent are EUSA members alone). Indeed if EUSA and UACES members are removed, then the proportion of political scientists among the total global ECSA population falls to 23 per cent. Of course, EUSA's membership extends beyond the territorial reach of the US, indeed it might reflect a perception of EUSA as the nodal point for scholars of EU politics worldwide. Indeed, EUSA's own membership statistics would seem to confirm this perception. Of a total membership in 2006 of $871,{ }^{5} 480$ scholars ( 55 per cent) are based in North America (of whom the vast majority -459 or 53 per cent - come from the United States). Some 377 (43 per cent) come form Europe. Of the European membership of EUSA, the British contingent numbers 119 (or 14 per cent of the total membership). The other national groupings claiming in excess of 50 members are Belgium and Germany with 59 each. ${ }^{6}$ EUSA's apparently cosmopolitan character is evidenced by the participation patterns at EUSA's biennial conferences, where a majority of delegates in 2005 were based in European institutions (Keeler, 2005: 574).

\footnotetext{
${ }^{5}$ Note the discrepancy with the macro data supplied by ECSA.

${ }^{6}$ All data quoted here is obtained from http://www.eustudies.org/organ.html, accessed 6 March 2006
} 
The pre-eminent role of EUSA as a hub for the study of EU politics suggests that English is the dominant medium of communication and that scholars in the field regard Anglophone academic work - rightly or wrongly - as the generator the most important writing about on European integration. More benignly, it might simply reflect the status of English as the de facto academic lingua franca (Wessels, 2006: 235).

But the facts that (a) so much work is produced in English and (b) scholars across the globe appear to cluster around the US based professional association tell us little about whether academic work on the EU is converging around a particular set of knowledge production norms. An obvious question concerns the extent to which the dominant approaches found in US political science dominate in turn the study of EU politics? Do the standard intellectual technologies act as a global benchmark for what counts as 'quality' work or 'progressive' research. An alternative hypothesis might speculate that the large numbers of non-US scholars working on the EU has brought particular theoretical traditions and local epistemologies into Anglophone work on EU politics and European integration.

\section{Academic journals and the EU studies 'mainstream'}

These questions are discussed in more detail below, but for now it is worth examining the extent to which explicitly non-mainstream work (i.e. that which eschews in one way or another the dominant epistemological and methodological preoccupations of US political science) engages with the mainstream. One way of measuring this is to look at the venues in which such work appears. In this volume Ian Manners (chapter 4) provides a systematic overview of 'critical' studies of European politics. Manners' extensive bibliography cites 53 papers published in academic journals, with a total of 32 journals mentioned. Of these, the two citations of pieces in European Union Politics (EUP) should be bracketed as 'non-critical' sources. Of the remainder, only two papers appear in journals (International Organization and International Studies Quarterly) normally associated with the practices of the US mainstream. ${ }^{7}$ Many of the other papers are scattered across (British) IR, critical political economy, critical legal studies, sociology and women's studies journals. Perhaps, therefore, we might

\footnotetext{
${ }^{7}$ Respectively, Ruggie, 1998 and Smith, 2004.
} 
speculate that while 'dissenting' or 'critical' work on the EU abounds, it is usually presented to and discussed within non-EU studies/political science academic communities. That would be to ignore the 13 cited articles that have been published by the two most prominent EU studies journals: the Journal of Common Market Studies (JCMS - 4 citations) and the Journal of European Public Policy (JEPP - 9 citations).

Table 3 presents the six journals that self-identify as outlets for the discussion of EU politics/European integration (as opposed to European politics more generally). ${ }^{8}$ of these, one (European Integration Online Papers) is a refereed working paper series and three (including JCMS and JEPP) possess ISI accreditation, meaning that articles appear in the Social Science Citation Index. The editorial balance is overwhelmingly UK/European, although the bi-lingual Journal of European Integration/Revue d'Intégration Européenne (JEI) was edited from Canada for many years.

Table 3: (English Language) Journals with a focus on 'EU politics'

\begin{tabular}{|l|l|l|c|}
\hline Title & Founded & Current editorial base & $\begin{array}{c}\text { ISI } \\
\text { status }\end{array}$ \\
\hline European Foreign Affairs Review & 1996 & UK & \\
\hline European Integration Online Papers & 1998 & Austria & \\
\hline European Union Politics & 2000 & Germany/UK/US & $\checkmark$ \\
\hline Journal of Common Market Studies & 1962 & UK & $\checkmark$ \\
\hline $\begin{array}{l}\text { Journal of European Integration/Revue } \\
\text { d'Intégration Européenne }\end{array}$ & 1978 & UK & \\
\hline Journal of European Public Policy & 1994 & UK & $\checkmark$ \\
\hline
\end{tabular}

With the outlier exception of EUP, each of these journals has identified itself (and by implication EU studies) as a place for conversations between disciplines. Uwe Kitzinger's editorial in the first number of JCMS announced the journal's aspiration to become 'a forum of high-level exchanges between scholars and policy-makers in different fields' (Kitzinger, 1962a: v). ${ }^{9}$ The JEI describes its focus as

\footnotetext{
${ }^{8}$ To these we might add major book series such as Palgrave Macmillan's 'European Union Series' and the 'New European Union Series' published by Oxford University Press. While these series are predominantly designed to produce textbooks, several other publishers such as Manchester University Press, Routledge and Rowman and Littlefield have marketed monographs on EU politics within the series format.

${ }^{9}$ The JCMS has always been edited by a mixture of scholars of politics and economics. The journal was edited exclusively by economists between 1980 and 1991 (Loukas Tsoukalis, 1980-1984 and Peter Robson, 1984-1991). Since 1991, the JCMS has followed a dual discipline editorial policy: Simon Bulmer (political scientist) and Andrew Scott (economist turned legal scholar), 1991-1999; Iain Begg
} 
'interdisciplinary or multidisciplinary ... thus integrating politics, economics, law, history and sociology'. ${ }^{10}$ The founding editorial of JEPP speaks of the journal's intention to draw upon the widest possible range of social scientific disciplines (Richardson and Lindley, 1994). JCMS editorials penned at moments of editorial change have always reaffirmed this founding commitment. But they also provide with important insights into how senior figures in EU studies were thinking about the field at particular moments in its development. Take Loukas Tsoukalis's argument when he assumed the helm at the JCMS in 1980: 'integration theory has been run into the ground, probably because we have been slow in realizing that this new and complex phenomenon could not be studied by our conventional tools of analysis' (Tsoukalis, 1980: 215). This stands in remarkably sharp contrast to those arguing the precise contrary: that the problem in the study of the EU has been the failure to properly embrace and apply conventional political/social scientific tools of analysis (see inter alia Dowding, 2000; Hix, 1994, 1996, 1998, 2005; McLean, 2003; Moravcsik, 1997, 1998, 1999; Pahre, 2005; Schneider, Gabel and Hix, 2000). New editors have also been keen to foresee their journals as responsive to conceptual and epistemological trends within the social sciences. JEPP, for example, is conceived as an expression of the maturity of policy analysis and its status as a 'rigorous scientific activity' (Richardson and Lindley, 1994: 1). Back in 1980 at the JCMS, Tsoukalis (1980: 215) was noting the affinities between the journal's scope and the emergent subdisciplinary project of international political economy (IPE) (see also Katzenstein, Keohane and Krasner, 1998; Murphy and Nelson, 2001; Verdun, 2005). Simon Bulmer and Andrew Scott's tenure would be attentive to the significance of legal scholarship and the points at which it might intersect with economics and political science (Bulmer and Scott, 1991; see also Shaw and More, 1995). Their successors (Begg and Peterson, 1999) identified 'globalisation' and 'governance' as new key macro-themes that would influence the study of the EU and suggested that scholarship would need to grapple with the institutional consequences of a wealth of local EU developments such as monetary union and the growth of foreign and security policy competence. The most recent JCMS editorial statement - attentive perhaps to the controversies raised by the 'perestroika' movement in US political science - moved

${ }^{10}$ http://www.tandf.co.uk/journals/printviw/?issn=0703-6337 (accessed 9 March 2006). 
on from statements about multi- and post-disciplinarity to claim the journal as a nonsectarian refuge for methodological and epistemological pluralism (Paterson and Rollo, 2004). Additionally there is a tendency to describe the focal point of these outlets as rather more than the EU (and its precursors). Indeed the JCMS, though obviously stimulated by the European experiments of the 1950s, was always keen to publish work on the growth of customs unions and common markets across the world as evidenced by the appointment of the Mexican-based Miguel Wionczek as joint editor in $1966 .^{11}$

Stark contrast is provided by the one EU politics journal, already identified as an 'outlier', EUP. While the opening editorial (Schneider, Gabel and Hix, 2000) anticipates contributions from across the social science spectrum and even intimates that the likes of postmodernism might find a place in the journal, there are some very clear pointers to the type of work that is likely to be (indeed has been) published. ${ }^{12}$ One of the most interesting features of EUP's first few years has been the publication of pieces by scholars who come from beyond the conventional orbit of EU studies, but are noted as leading protagonists in particular areas of political scientific enquiry. These papers review the 'progress' of the study of EU politics in light of clearly rationalist benchmarks (see Dowding, 2000 on rational choice institutionalism and McLean, 2003 on the analytic narratives approach). Take also what might be called the two 'founding complaints' of the journal. First there is an argument that work on EU politics was dominated by 'grand' IR theories (Schneider, Hix and Gabel, 2000: 6). Second, the journal's existence is justified because the study of EU politics 'does not yet possess an outlet that concentrates on the most advanced and methodologically sophisticated research papers' (Schneider, Hix and Gabel, 2000: 6). This, of course, implies that none of the extant journals on the EU perform this task adequately. Instead the best papers are held to be scattered throughout a range of general political science journals and EUP is designed to act as a rallying point for such work.

It is of course true that a full audit of research on EU politics cannot be confined to the output of sources that are auto-defined as 'EU journals'. John Keeler's (2005)

\footnotetext{
${ }^{11}$ Wionczek remained as joint editor until 1979.

12 Jupille (2006: 225) finds EUP to be, in methodological terms, the most formal and statistical and the least qualitative of the five journals he surveys (the others are the European Journal of International Relations, International Organization, JCMS and JEPP).
} 
extensive mapping of the development of EU studies between 1960 and 2001 sought data on the publication patterns of 24 journals, thereby looking at not only EU studies periodicals, but also the primary political science journals of five countries and over a dozen more general politics and IR outlets. To examine the trends of EU studies within the US, Joseph Jupille (2006) opts to examine the EU-related output of two journals in each of two main subfields (comparative politics and IR) in American political science. It is difficult to miss the importance of International Organization (IO) as a long-standing arena for the discussion of European integration and the dynamics of EU politics (Katzenstein, Keohane and Krasner, 1998). Indeed, to ignore $I O$ 's output in the 1960s and early 1970s in favour of, say, the JCMS would almost certainly leave the reader with a very skewed impression of the significance of and the internal discussions within neofunctionalism.

\section{Conventional narratives of the study of EU politics}

Within EU studies, there are several very well established claims about the history of the field and scholars have provided multiple reconfigurations of the past. The story is usually told sequentially in terms of a number of staging-posts. Theoretical debate and evolution is the most obvious hook upon which the narrative is hung. But precisely how this is done and with what purposes and consequences varies.

Within the mainstream Anglophone literature it is relatively easy to identify a series of theoretical points of reference around which much EU studies work has been organised (see Rosamond, 2000 for a full account). Normative federalist thinking is often bracketed with David Mitrany's functionalist theory of institutional design and Karl Deutsch's transactionalist account of the formation of security communities to form a set of precursor theories, which fed - in various ways - into the thinking of the first generation of scholars to grapple properly with the institutions of post-war integration - the neofunctionalists. Neofunctionalism, in its classical incarnation, is thought to be bounded at one end by the publication in 1958 of Ernst B Haas's The Uniting of Europe and at the other by a couple of essays from the mid 1970s, also by Haas, in which regional integration theory was declared 'obsolescent' (Haas, 1975, 1976). In the interim neofunctionalism had been exposed to a powerful intergovernmentalist critique (Hoffmann, 1966 is always cited; see also Hansen, 
1969), but for many its primary problem was its incapacity to build a general predictive theory of regional integration from its inductive engagement with the early European experience. A cautionary theoretical atmosphere came over EU studies throughout much of the 1970 s as social science more generally became less enamoured with the ambitions of grand theory, choosing instead to focus on the 'mid range'.

Events within the Communities during the 1980s, yielded a series of attempts to revive and update neofunctionalism, but also induced the composition of a systematic liberal intergovernmentalist theory (Moravcsik, 1998). Meanwhile, scholars from comparative politics and policy analytic traditions flocked to the EU as an object of study, bringing with them a host of concepts and theories. This led to the EU being theorised less as a case of 'integration' and more as a 'polity' or a 'political system', although there remained some quite profound disagreements about whether the object was a transcendent or familiar phenomenon. The EU came to be treated variously as a classic Lasswellian polity, a proto-federation, a system of (multi-level) governance or as a test case for one of the three emergent 'new institutionalist' paradigms.

By the late 1990s, there was significant momentum in three further areas. First, despite the powerful arguments of comparativists and policy analysts, the growth of EU foreign policy competence seemed to clear the way for theories of IR and foreign policy-making to (re-)enter EU studies (Andreatta, 2005; Jørgensen, 2004; White, 2001). Second, the injection of constructivism into EU studies (largely from IR, but also from European social theory) provided a major theoretical challenge to the repertoire of 'rationalist' approaches to both integration and the EU polity and took debate in EU studies into the domain of metatheory.. Third, concerns about the EU's legitimacy and democratic credentials fed a growing interest of the application of normative political theory to the EU. Beneath these broad umbrellas sit a diverse array of theories and approaches.

The creation of a narrative (such as that of the previous paragraphs) is a far from neutral exercise. For example, there is a clear implication, tackled more systematically in what follows, that one of the major stimuli for change or reordering in the EU studies theoretical repertoire has been the changing nature of the EU itself. Moreover, 
simply by telling the story sequentially, such accounts are naturally prone to privilege present theoretical efforts over those of the past - or at the very least it begets the unexamined assumption that the theoretical work of 30-40 years ago was beset with problems and difficulties.

\section{Organising stories about EU studies}

The standard story of EU studies may be straightforward enough, but it can be organised in different ways and with different purposes. As a prelude to the final sections of this chapter, which explore some of the standard modes of organising this story, this section examines three 'meta' issues of concern. These are, respectively, whether there should be a (disciplinary) mainstream in EU studies and the derivative questions of what constitutes 'progress' in the field and to what conceptions of social science should EU scholars subscribe.

\section{Mainstreaming versus pluralism}

Much of the foregoing points to an ongoing disagreement within the field of EU politics about both its proper scope as a branch of social scientific enquiry and the appropriate way(s) in which is should seek to accumulate knowledge. Table 1 presents a heavily and deliberately stylized ideal typical version of this debate, representing the opposition between two broad ideal types - labelled here the 'mainstreaming' model and the 'pluralistic' model. Each model contains three functionally equivalent propositions designed to show the potential scope of disagreement within the field about (a) disciplinary co-ordinates, (b) epistemological and methodological commitments and (c) the ontological relationship between the object (the EU polity) and the intellectual tools needed to study it.

\section{Table 1: Two models of the study of EU politics}

\begin{tabular}{|c|c|}
\hline THE MAINSTREAMING MODEL & THE PLURALISTIC MODEL \\
\hline $\begin{array}{l}\text { The study of EU politics is best served by the } \\
\text { standard tools of political science. }\end{array}$ & $\begin{array}{l}\text { The study of EU politics is an inherently } \\
\text { multidisciplinary affair. }\end{array}$ \\
\hline $\begin{array}{l}\text { Good political science conforms to a set of } \\
\text { standardized epistemological positions and } \\
\text { methodological rules of thumb. }\end{array}$ & $\begin{array}{l}\text { The study of EU politics benefits from the input } \\
\text { of work from diverse epistemological and } \\
\text { methodological standpoints. }\end{array}$ \\
\hline The EU is a polity 'like any other' that lends itself & The EU is a new $\mathrm{t}$ \\
\hline
\end{tabular}


The debate is presented in this simplified version for heuristic purposes. It might be that these two positions are better thought of as a continuum, with most scholars taking up a position somewhere along a line plotted between these two polar views. In particular it is important not to fall into the trap of assuming that all work on the EU emanating from formal theory and using quantitative methods sits at the extreme 'mainstreaming' end of the continuum (Pahre, 2005). Moreover, from one angle at least, these two broad images of the field are not wholly incommensurable. From the position of the pure 'pluralist', enquiry building upon the propositions of the 'mainstreaming' model is perfectly acceptable - so long as it remains one approach amongst many (Wallace, 2000). The 'ultra' version of the mainstreaming model, however, takes an extreme Kuhnian stance in that its understanding of science and scientific progress is predicated upon the idea of scholarly communities working around tightly policed sets of norms ('normal science') where there is little space for deviance or dissent (Kuhn, 1996; on EU studies implications see Manners, 2003). Of course, these arguments and oppositions are not confined to EU studies. Controversies of scientific exclusivity versus methodological/epistemological pluralism sit at the heart of the 'perestroika' movement's critique of the allegedly exclusionary practises of mainstream American political science (see inter alia Dryzek, 2002; Lubomudrov, 2002; Mearsheimer, 2001 and, more popularly Cohn, 1999).

The pluralistic position is obviously tolerant of the so-called critical approaches discussed in this volume by Ian Manners (chapter 4), regardless of their epistemological credentials. As we move to towards the 'mainstreaming' pole, so the quality of 'critical' work comes to be scrutinised for the extent to which it fits a standard model of theory building (Pahre, 2005). For example, one of the interesting debates within the constructivist tradition (see Checkel, chapter 3) - a debate that has been played out explicitly within EU studies - concerns the extent to which constructivism should seek to share the same epistemological territory as rationalism (Pollack, chapter 2). Self-defined 'constructivist' work on the EU actually covers a vast metatheoretical territory (Christiansen, Jørgensen and Wiener, 2001) with scholars dispersed across a continuum between 'rationalist' and a 'reflectivist' poles 
(Keohane, 1988). There would seem to be two distinct 'constructivist' positions, one of which leans significantly towards the 'mainstreaming' pole. The debate between Jeffrey Checkel (2001a, 2001b) and Andrew Moravcsik (2001a) is organised around the degree to which constructivist work on the EU can conform to standardised theory building norms (an aspiration clearly associated with the IR constructivist project of Alexander Wendt, 1999; see also Wendt, 2001; Fearon and Wendt, 2002). Moravcsik's various critiques of the more reflectivist work on EU constructivism (Moravcsik, 1999b, 2001b) assess such contributions in relation to a series of benchmark definitions of 'good' social science practice (the formulation of explicit hypotheses that make possible disconfirmation and research design that allows replication - see also Moravcsik, 1997, 1998: ch. 1). ${ }^{13}$

A further question that follows from the presentation of the two models is quite simply to wonder whether they are reflective of different traditions in the study of politics: crudely, one 'American' (aspiring to scientific naturalism, theory driven, aspriring to 'normal scientific' synthesis ${ }^{14}$ ), the other 'non-American' (historicist, influenced more by broader social theoretic currents) (Wallace 2000: 103; Wæver 1998: 724). This contrast is drawn frequently enough. The assumption of a historic transatlantic divide in EU studies has achieved the status of a 'stylised fact', to coin a favourite rationalist phrase. Amy Verdun (2005), for example, draws a contrast between theory-oriented 'American' research on the EU and 'European' case studyoriented work. The latter are - in effect - 'EU-ists' first and foremost, while the latter are 'political scientists' who use the EU as a case. The first British evaluations of the early American work on the communities seems to predict the 'two traditions', with reviewed apparently bewildered by the use of theory. Take the founding editor's discussion of Haas's The Uniting of Europe in the JCMS: '[ $\mathrm{t}]$ he conceptual discussions of the first chapter re tough going and British readers might be tempted to ask if the ponderous terminology assists as much as it impresses the ordinary student' (Kitzinger, 1962b: 189). ${ }^{15}$ There is an ongoing scepticism about (American) deductive, theory-driven work, which - allegedly - privileges theory over the

\footnotetext{
${ }^{13}$ For an aggressive critique of Moravcsik's work in its own methodological terms, see Lieshout, Segers and van der Vleuten, 2004.

${ }_{15}^{14}$ See Milner, 1998 on this particular point

${ }^{15}$ Again, caution should be urged. Volume 4 number 1 of the JCMS contained an important, though now rarely cited, paper by Kaiser (1965) on the virtues of the American theory-driven approach, while volume 5 number 4 (1967) contained pieces by Haas and Lindberg.
} 
accumulation of empirical knowledge. Much of the historical work on the EU (see Milward's essay in chapter 5 of this volume) is built around a powerful defence of inductive research strategies in opposition to the supposed simplifications of history that characterised the first generation of deductive integration scholarship (Kaiser, 2006; Milward, 1992; Milward and Sørensen, 1993; Dinan 2006).

Yet, we have to be very careful with such bold 'two camp' characterisations of EU studies. In particular, a literal understanding of this divide as purely geographic is likely to miss significant nuance. More productive is a sociological use of the terms 'European' and 'American' as signifiers of distinctive epistemological commitments, themselves embedded within distinctive cultural-institutional contexts (Wæver, 1998). So, for example, we cannot understand the conduct of work on the EU that emanates from political scientists within US institutions, without understanding (a) the various scholarly norms that govern the admissibility and quality of academic research and (b) the incentive structures that prevail within the profession (Wagner, Wittrock and Whitley, 1991; Whitley. 1984). Therefore, the interesting question surrounds the extent to which culturally bound modes of knowledge production become influential beyond their locale (i.e. to what extent are they globalized?). Geography matters in so far as the social sciences (indeed disciplinarity more generally) are strongly rooted within the logic of nation-state (Mancias, 1987), but it is the spread of scholarly styles and their capacity to penetrate 'alien' academic cultures that provokes interest.

Jupille's (2006) systematic overview of metatheoretical and methodological cleavages within EU studies shows how the assumption of a straightforward geographic divide between 'American' and 'British' and/or 'European' approaches to EU politics can miss some key arguments. At the same time, Jupille offers a very helpful cartography of approaches that exist at a level higher than precise theoretical choice (say neofunctionalism versus intergovernmentalism; sociological versus rational choice institutionalism), but which at the same time helps us to understand why scholars make those theoretical choices and make particular methodological commitments. It helps us to gather together some of the points made already. The first three cleavages identified by Jupille (ontology, epistemology and social theory) in effect account for the divisions between and the debates within the three broad schools of theory rationalism, constructivism, critical approaches - that the three following chapters 
review. The fourth and fifth cleavages are, respectively, disciplinarity and scholarly style. As suggested already, a priori stances towards both of these are likely to be profoundly influential upon how scholars formulate puzzles, make theoretical choices and conduct the research process. A comparativist based in a top 10 US political science department with an interest in EU politics will make theoretical and methodological choices, but not altogether within conditions of her own choosing (see also Wiener and Diez, 2004b).

\section{'Progress' in the study of EU politics}

Different locations on an imaginary continuum between the 'mainstreaming' and the 'pluralist' position bring with them alternative understandings of progress in the field. The stylized 'mainstreaming' position is confident in political science's capacity to improve progressively its intellectual technologies over time. As such, the stock of secure social scientific knowledge is improved. The advantage of 'mainstreaming' as a strategy is precisely that it exposes scholars of the EU to the most advanced techniques available. Empirical advancement is inevitable, particularly since such techniques provide insurance that appropriate levels of analytical leverage are achieved (i.e. the EU is not reduced to the status of a single $n$ ). At the other end of the scale, 'pluralists' (some of whom - particular strands of postmodern science in particular - are actively hostile to the disciplining notion of 'progress') are cautious about bold claims of advancement, particularly if they amount to arguments that some traditions of work should be discounted as useless. A pluralist take on the study of EU politics would imagine the productive coexistence of multiple approaches, each with its own internal understanding of scholarly advancement. This, of course threatens a kind of intellectual 'Balkanization', where a series of academic tribes co-exist, but rarely communicate (Jupille, 2006). The solution - from a pluralist stance - is to facilitate communication without imposing one tribe's version of how research is justified and evaluated.

\section{Social science and the study of EU politics}

The two models rather obviously have different understandings of the kind(s) of social science we need to know in order to study EU politics. By definition, the 'mainstreaming' pole of the continuum takes the view that the authorized mainstream of political science supplies the reference stock for the scholar of the EU. Scholars 
should be 'trained' according to the standard manuals of (US) graduate courses (for example, King, Keohane and Verba, 1994), be acquainted with the latest ideas in how to provide rigour to case based empirical work (for example Bates et al, 1998), understand the latest formal and statistical techniques and draw inspiration from the best research published in the world's leading political science journals (which in all likelihood will investigate cases other than the EU). As these norms spread and become embedded, so progressive research programs on EU politics - umbilically linked to other research programs - will emerge and empirical knowledge will advance.

The alternative position imagines that wide and eclectic reading should inform the study of EU politics. It distrusts the secure foundations attributed to standard political science by the 'mainstreamers', and perhaps draws attention to very broad metadevelopments across intellectual life that closed Kuhnian communities miss (Manners, 2003). Inevitably this becomes an argument for multi- or interdisciplinarity (Cini, 2006; Rumford and Murray, 2003) and places its advocates towards the 'complexity' side of what Colin Hay (2002: 34-37) labels the 'parsimony-complexity trade off'. But it also forces us to examine arguments that, instead of privileging discipline-based knowledge production, actively celebrate studies of 'the particular'. These arguments in turn are not comfortable with ideas such as Robert Bates' maxim that 'area studies has failed to generate scientific knowledge' (1996: 1), seeing them as imperializing interventions on behalf of particular approaches (Johnson, 1997). Pure disciplinarity brings with it a search for global/universal laws of political motion. This assumes, a priori, that localities/regions are, at a crucial level, not context bound and subject to particularistic dynamics (Appadurai, 1996). This axis of debate has been particularly important to discussions about European studies in the United States (Calhoun, 2003), where expectations brought by disciplinarity norms have been read as threats to the nurturing of area and regional expertise (Hancock, 1999; Rosenthal, 1999).

\section{Understanding the course of the study of EU politics}

It follows, of course, that quite different readings of the history of EU studies follow from the various oppositions that emerge from alternative models of the study of EU politics. For example, an assumption of the progressive advancement of political 
science over time carries the axiological consequence that EU studies is in a better place now than it was in the past, precisely because of the recent arrival into the field of advanced techniques. It is not just the structure of the narrative, but its substance which is at stake. As we move towards the 'mainstreaming' position, so the story of the study of EU politics comes to be more and more about application of political science to the EU, at the expense of other starting points. In other words, it is easy to slip into a way of telling history that (a) places the 'present' as the telos to which all hitherto existing theory leads and (b) treats earlier phases of work as necessarily 'prototypical of the present' (Gunnell, 2005: 597). Conventional (textbook) narratives of IR have been criticised precisely because of this tendency towards 'presentism' (Schmidt, 1998, 2002; Smith, 2000b; Williams, 2005; Wæver, 2003). Thus the oft heard claim that IR is about the problem of inter-state war actively excludes work from the canon that is not premised on the discussion of this topic. Auto-definition produces a narrative (and polices the discipline's borders) in ways that confirm the authority of that auto-definition. The same is true of IR's theoretical canon, where recent scholarship suggests that the linear link (assumed by both neorealists and their critics) between realism and neorealism is dependent on serious misconstrual and simplification of the breadth and substance of classical realist writings (Murray, 1997; Williams, 2005). Claims about the past of the field are - in effect - moves that frame notions of disciplinary and theoretical authenticity in the present. The story of the field is likely to be told differently by observers with diverse takes on the present state of the art. Three ways of organising the state of knowledge in EU politics are presented here.

The first is to map theoretical change against empirical change. The presumption here is that there is and should be a close relationship between (a) the study of EU politics and (b) the 'real world' conduct of that politics and the institutional contexts within which it takes place. Thus Jeffrey Anderson (1995) argues that the opposition between neofunctionalism and intergovernmentalism is rendered yet more sterile by the growing complexity of the EU from the 1980s on. The 'old' theories produce 'narrow puzzles that differ only at the margins and that lack empirical and theoretical reach' (Anderson, 1995: 455). The solution is to turn to tools from comparative political economy (theories of negotiating and bargaining), rational choice theory, policy analysis (policy network analysis) and political science (the new 
institutionalisms). Diez and Wiener's (2004) classification of EU theory relies upon a three phase movement, where each phase is defined by a macro-puzzle, which in turn corresponds to a particular phases in the EU's history. The first phase sees scholarship seeking to 'explain integration' (1960s onwards) following the founding Treaties. The second phase (from the mid-1980s) is organised around the analysis of 'governance' and the EU polity (following the SEA). The third phase (from the 1990s), labelled 'constructing the EU' reflects the important appearance of constructivist analysis, but also addresses the important normative and constitutional implications of recent treaty reforms. In a slightly different light, Keeler (2005) divides EU studies into three phases in which the fortunes of academic work wax and wane in a co-variant way with the fortunes of the EU: the 'launch era', where the empirical driver was the Treaty of Rome (and presumably the Treaty of Paris before it) and debate was organised around the opposition between neofunctionalist and intergovernmentalist theories of integration; the 'doldrums' era after the 'empty chair crisis' in which theoretical work stagnated and grand theorising became a no-go area in EU studies; and the renaissance/boom era that followed the relance of integration from the mid1980s. ${ }^{16}$

A second common way of thinking about the evolution of EU studies involves the organization of classifications of the present field in ways that rely upon a kind of intellectual 'throat clearing' in which the history of EU studies past is reconstructed. This is very commonplace in the EU studies literature, so only a few prominent and interestingly contrasting examples are offered here. Simon Hix (2005) presents the field in the here and now as clustered into three broad schools: liberal intergovernmentalism (LI - as elaborated by Moravcsik), an assortment of approaches that share the central concept of 'governance', and rational choice institutionalism. Of course, these are hardly functional equivalents. LI is - to all intents and purposes - the intellectual project of a single scholar (Schimmelfennig, 2004) ${ }^{17}$, whereas the governance school is a loose coalition of sub-schools with variable epistemological commitments. Meanwhile rational choice institutionalism is characterised by a rather more coherent intellectual community that intervenes in the study of EU politics from

\footnotetext{
${ }^{16}$ Keeler's conclusions follow a quantitative analysis of dissertation production and journal article production between 1960 and 2001 rather than an analysis of changing theoretical trends.

${ }^{17}$ As Schimmelfennig (2004: 75) rightly notes, LI emerges out of the rationalist (liberal) institutionalist tradition in IR (see also Rosamond, 2000: 142).
} 
the epicentre of US political science. These three approaches deserve their status as inductees into the present state of the art because they represent departures from at least one of two errors of previous work. In the first place, each contains the potential to generate testable propositions in the empirical context of the EU - a deep problem of EU studies past (see also Moravcsik, 1997, 1998). Second, each of the three represents an escape from the disciplinary straitjacket of IR, which cast the study of EU politics as a series of puzzles about 'integration', when in fact the EU had come to function as a polity/political system (on which, see Hix 1994; 1996). The most obvious casualty of both the move away from IR and the appeal for rigorous academic standards is neofunctionalism. As Moravcsik notes, '[f]rom 1958 to the late 1980s, neofunctionalism was the only game in town' (Moravcsik, 2005: 357). In many ways the neofunctionalist scholars were responsible for the totality of integration theory for much of the $1960 \mathrm{~s}$ and 1970s. ${ }^{18}$ Therefore, to deny neofunctionalism a place at the contemporary table is to cast very serious doubt on the credentials of the entire field's past.

Hooghe (2001) lists three contenders as rival 'macrotheoretic' models for the study of EU politics - united by (the political scientific) aspiration to produce comparative insights across cases. They are LI, a revised version of neofunctionalism (associated with Sandholtz and Stone Sweet, 1998) and multi-level governance (MLG). This is a slightly revised version of the position developed earlier by the MLG school, where MLG is presented as an emerging and coherent rival to LI (Marks, Hooghe and Blank, 1996). As such MLG seems, initially at least, to have displaced neofunctionalism as the main pole of non-intergovernmentalist thinking on the EU. MLG scholars were very keen to show how their approach spoke directly to the changing nature of the EU (Marks, Hooghe and Blank, 1996: 373), where new, multi-layered, multi-actor, fluid modes of governance made the simplistic, two-level game imagery of LI appear both empirically sterile and analytically limited (Marks et al, 1996). Moreover, the MLG literature on European integration was but a small segment of a wider analytical and normative literature found in local government studies, public policy analysis, comparative federalism and IR on the changing forms and spatialities of governance (Hooghe and Marks, 2003).

\footnotetext{
${ }^{18}$ The significance of this point will vary with the extent to which neofunctionalism is understood as a static theory (see below and Rosamond, 2005).
} 
In contrast, Mark Pollack (2005a, 2005b) prefers to depict the state of the art as consisting of three coexistent communities, within which the degree of scholarly consensus varies from fundamental metatheoretical disagreements to the practice of something resembling a Kuhnian 'normal science'. The first of these is the (IR) debate between rationalist-constructivist approaches, which Pollack sees as displacing the rivalry between the two classical rationalist theories (neofunctionalism and intergovernmentalism). ${ }^{19}$ Pollack's second community finds a 'spiritual home' in EUP (Pollack, 2005b: 370) and clusters together those scholars who have brought the tools of (mainstream rationalist) comparative political science to bear upon the study of legislative, executive and judicial politics of the EU. This work proceeds via the maxims of 'normal science' and quite obviously builds upon insights from mainstream American political science about aspects of American politics. More diverse, potentially less rationalist and certainly less 'American' is the group of public policy, ideational and social theoretic approaches which utilize the concept of 'governance' (on the growth of the concept see van Kersbergen and van Waarden, 2004). The development of these three traditions in EU studies, once again is seen as a vast improvement upon the analytical blind alley of neofunctionalism versus intergovernmentalism.

The third narrative of evolution of the study of EU politics follows the second's implicit progressivism - but others are much more explicit in their claims that the EU is in a far superior state of health now than in was in the past. More often than not, this move cites as the primary drivers of this new rigour the growth of formal and statistical modelling in EU studies and the appearance of work that openly subscribes to the theory building norms of US political science. Following the publication of Moravcsik's The Choice for Europe (Moravcsik, 1998), Caporaso maintains that. [s]tandards that apply in other sub-fields, for example, with regard to research design, data collection, and analysis, are more likely to extend to regional integration studies also (Caporaso, 1999: 161). In a jointly authored paper, one of the editors of EUP has written that '[n]eoinstitutionalist research has played a central role in the

\footnotetext{
${ }^{19}$ Haas (2004: xvii, fn.5) remarked on the metatheoretical similarity between neofunctionalism and LI. Both constructivists and rationalists seem keen to claim neofunctionalism for their own side of the divide (see Börzel, 2006).
} 
professionalisation of EU politics, and it does not seem inconceivable that the subfield will become an exporter of new analytical tools rather than the passive importer it has been for decades' (Schneider and Aspinwall, 2001: 177, my emphasis). Iain McLean, welcoming the arrival of game theoretic work and theories of social choice into EU studies, reflects that '[f]or the first three decades of the existence of the EU and its predecessor organizations, almost all social science literature on it of which I am aware was purely descriptive' (McLean, 2003: 499, my emphasis). Keith Dowding (2000) writes approvingly of rational choice institutionalist work as the 'normal science' of EU studies.

It should be quite clear from the foregoing that these disciplinary histories narrate the evolution of the study of EU politics in often quite distinct ways, perhaps reflecting a particular theoretical or social scientific preference located in the present. Having said that, there does seem to be some common ground - around the likes of (a) the existence of a period of theoretical decline/stagnation that coincided with the Communities' own crises/Eurosclerosis of the 1960s and 1970s, (b) the displacement of IR in general and neofunctionalism in particular, (c) the rise to prominence quite recently of comparative politics and governance approaches, and (d) a general sense of improvement and progress in the field that some associate with the insertion of rigour and a logic of 'mainstreaming' into a hitherto 'backward' and 'ghettoized' field.

\section{'Internalist' and 'externalist' accounts of EU studies}

What also follows from these narratives of EU studies history is an understanding that changes in the object of study (the EU) have accounted for the changing anatomy of the field in terms of the theoretical traditions and scholarly communities that populate it. As Ole Wæver (2003) notes, the intellectual evolution of a field is often thought of as being closely tied to developments within the object of study. Thus it might be argued that the trajectory of EU studies in general its theoretical repertoire in particular is a function of the changing nature of the EU over time. So to pick out some random examples, neofunctionalism might be read as an intellectual expression of the strategies employed by European elites that were embodied in the Schuman Declaration of 1950 and the subsequent institutional design of the early Communities. Similarly, the appearance of intergovernmental critiques and the collapse of the 
neofunctionalist project appear to be reactions to the growing visibility of national executives and intergovernmental institutional expressions in the Community system from the mid-1960s. The increasing tendency of current literature to conceptualise the EU as a political system can be traced to the obvious salience of the EU as a supplier of authoritative outputs and the attendant complexity of the multi-actor policy process that surrounds the EU's institutions. Finally, the rapid recent growth of studies of the external dimensions of European integration may seem an obvious consequence of (a) the growth of foreign, security and defence policy agendas and competencies, (b) the emerging status of the Euro as an alternative reserve currency and (c) the widening issue base of international trade that has forced issues of European integration (such as the Common Agricultural Policy) onto the agenda of the World Trade Organisation.

Following Wæver (2003 and Schmidt, 1998), there are two variants of such an externalist position. The first celebrates this process as a sign of disciplinary progress in which EU studies has drawn valuable lessons from its object of study though a process of intellectual 'catch-up'. From this stance, it is imperative that EU remains an academic expression of the 'real world' of European integration and EU governance. Therefore, approaches to the EU that no longer 'fit' their object are candidates for disposal, although there may be cases where reinstatement is merited if the tide of integration shifts back in the direction of certain perspectives. ${ }^{6}$ The second position is rather more critical. Here scholarship is interrogated for its potential to act as the intellectual legitimation of particular ideologies associated with the object of study. A good example from EU studies is to be found in Alan Milward and Vibeke Sørensen's energetic critique of neofunctionalism, where the latter is portrayed as both (a) a Cold War theory offering an intellectual justification for US foreign policy priorities of the 1950s and (b) an attractive set of categories for the emerging supranational European elite to deploy in defence of their claims for the growth of Community-level governance capacity (Milward and Sørensen, 1993; see also White, 2003).

Wæver maintains that 'external explanations can sometimes ... be better at accounting for the overall directions of change [in a field], but they can never explain the form that theory takes' (2003: 5). So, for example, institutionalist approaches may 
appear to sit well with the broad treaty-induced and path dependent pattern of EU politics, but this cannot explain why rational choice institutionalism (for example) has been applied so readily to the EU and why rationalist epistemologies are claimed to offer the basis for a coherent research programme that brings together the various insights of the three institutionalisms (Schneider and Aspinwall, 2001). Pollack's (2005a, 2005b) ascription of the term 'normal science' to a body of comparative work on the EU is highly appropriate because it proceeds from a set of shared axioms about the construction, evaluation and epistemological foundations of research, which together constitute measures of 'quality' that apply especially within the dominant circuits of US political science. If work aspires to the 'kite mark' of quality (with all that implies), then it is barely surprising that so much emerging American work on EU politics conforms to this tradition.

Wæver's distinction between 'externalist' and 'internalist' readings of disciplinary history resonates with Wolfgang Wessels' (2006) discussion of pull' factors (from the EU) and 'push' factors (from the discipline) that together act as drivers of the changing shape of EU studies. Any proper discussion of the study of EU politics needs to understand both of these dimensions. Indeed, the 'external'/'push' and 'internal'/'pull' framework gives us a useful way into critical analysis of the various extant formal and informal disciplinary histories of EU studies. It also shows how academic work operates within certain 'conditions of possibility', governed by both its object and the sociology of academic enquiry at different points in time. We should also recognise that 'external'/'push' and 'internal'/'pull' factors do not operate independently of one another.

Put simply, how we read the evolution of the EU is a function of the intellectual lenses we use. The description of the EU at particular moments in its history is an act that cannot occur independently of an a priori conceptual vocabulary that facilitates that description. Thus the EU can be defined in ways that favour either standard political science treatments or less orthodox, cross disciplinary or 'critical' approaches (on the latter, see Geyer, 2003). Moreover, descriptions of the EU are also often re-descriptions of a particular phase in the EU's history from a point where new disciplinary conditions of possibility apply. A good example, is the presumption of the period of 'Eurosclerosis' between circa 1966 and 1985 - a period whose 
'bookends' are the empty chair crisis and the Luxembourg compromise in the 1960s and the publication of the Commission's White Paper on the internal market in the 1980s. Daniel Wincott (1995) shows how an intergovernmentalist reading of the Communities, with its expectation that key integration moments coincide with grand member-state bargains, is bound to construct this period as sterile because it brackets as insignificant everyday institutional interaction and key acts of jurisprudence by the European Court of Justice (see Christiansen and Jørgensen, 1999; Weiler, 1991).

Keeler's (2005) discovery of a 'doldrums' period in academic research on European integration that coincides with the 'Eurosclerosis' period is an important finding, but it might show a prevailing perception amongst established scholars and prospective doctoral students, armed as they were with particular intellectual technologies, that there were few (perhaps no) interesting academic puzzles resident within the Communities. That perception relies upon a description and the description in turn may represent the limitations of the political science of the time, rather than anything inherent within the Community system. At the time, one prominent scholar of the Community system was arguing that de Gaulle's interventions were not brakes on integration, but rather attempts to re-calibrate the nuances of the balance of policymaking forces within an already institutionalized Community model (Lindberg, 1996; see also Inglehart, 1967). Pushed to its post-positivist limits, this type of argument leads to complex arguments about the co-constitution of subject and object. Steve Smith discussed the application of 'rationalist' theory to European integration as follows: 'far from being the explanatory theory that it claims to be, instead provides a political and normative account of European integration whereby (positivist) notions of how to explain a given "reality" in fact constitute the reality of European integration' (2000a: 33, emphasis added; see also Bailey, 1996).

Figure 1 offers a broad framework for engaging with standard disciplinary histories of EU studies/the study of EU politics. It places emphasis on the importance of and the interaction between 'internal' and 'external' drivers of the field's development. It adds a third driver, which is identified explicitly by Liesbet Hooghe (2001). She suggests that the appearance from the 1980s of comparative politics research on the EU had much to do with the fact that systematic EU-level data sets were created and became available to the academic community. Thus the archive of Eurobarometer 
data, the appearance (from 1979) of European Parliament electoral data and the vast amounts of material generated by the Commission through Eurostat created a resource that allowed scholars of a particular inclination to utilise the EU (or parts of it) as a case. This important observation reinforces the point, developed above, that our objects of study do not exist independently of our readings of them. It also pushes the idea that objects of study are responsible for defining themselves in ways that allow academic analysis. To this should be added the array of supports for EU studies research and pedagogy that were identified earlier in this chapter. Thus the 'knowability' of the EU to political science is something that develops and changes over time.

\section{Figure 1: A framework for critical disciplinary history of EU studies}

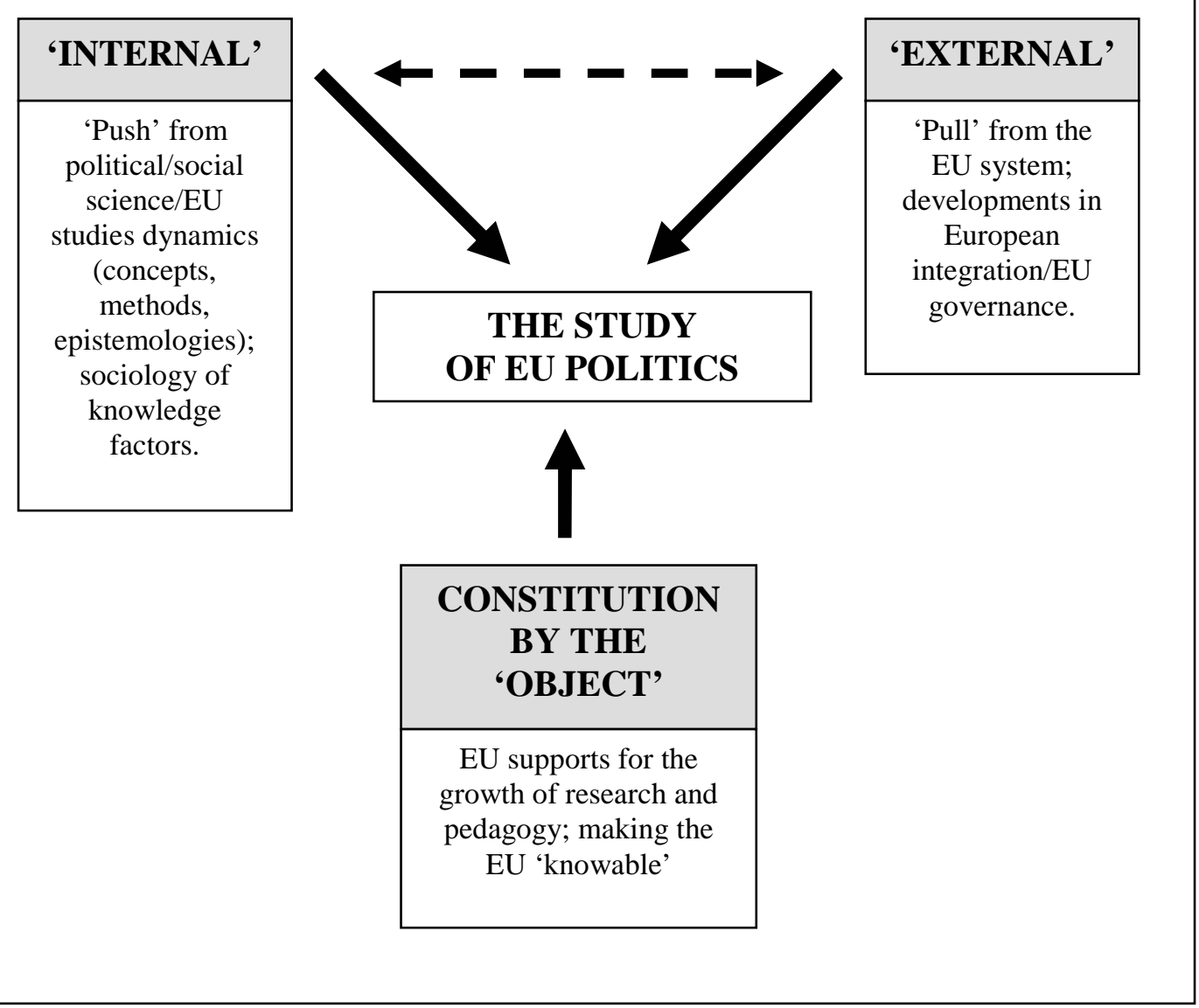

How then, might such a framework be used to make an intervention in the discussion of the development of work on EU politics? The foregoing ought to suggest that it is very difficult to write singular histories of the field and that perhaps the task of intellectual historians to perform a kind of 'double reading' where existing accounts 
are exposed to critical scrutiny in light of the framework presented here. This might involve the identification and evaluation of the types of moves that are made in the writing of stories of the field, not simply to judge the empirical plausibility of those moves (for example, is the rejection of neofunctionalism justified when we re-read the original neofunctionalist texts?), but also to understand the reasons why such narrative moves are made in the first place (for example, does the rejection of neofunctionalism clear the way for certain claims about the appropriate theoretical scope of the field in the present?).

For illustrative purposes, the remainder of this chapter is devoted to the interrogation of two broad and recurrent claims, which tend to point an accusatory finger at neofunctionalism (see also Rosamond, 2005): (a) the idea that the study of EU politics has moved beyond the sterility of IR and (b) the idea that EU studies past was characterised by unrigorous descriptive work that had no potential for the achievement of analytical leverage.

It is certainly true that Ernst Haas understood his own coordinates (and by extension those of neofunctionalism) as lying within a series of recurrent IR debates (Haas, 2004: xiv; Kreisler, 2000). But - crucially - Haas's project involved assaulting the prevailing realist and liberal wisdoms from two flanks: one empirical and the other epistemological-methodological. The second of these was directly connected to a commitment the professionalized norms of standard contemporaneous political science (Ruggie et al, 2005). This casts doubt on any attempt to classify neofunctionalist work with the (in this case) pejorative label of 'IR'. Haas (2001) described such acts of labelling as 'silly'. Indeed, Haas and the neofunctionalists drew much breath from the growth of pluralist political science in the US. This meant not only that integration and the emergent EU system were conceived as analogous to the operation of domestic pluralist polities, but also that the standards of theory building (the specification of variables and the postulation of testable hypotheses) were mainstream and - by the standards of the time - highly sophisticated. If this was IR, then it was IR that operated at political science's cutting edge (see in particular the contributions to Lindberg and Scheingold, 1971). 
Much of the integration theory project of the 1960s and 1970s was actually conducted largely in terms of a nuanced conversation among neofunctionalists. The scattered intergovernmentalist critiques (particularly that of Hoffmann, 1966; less so that of Hansen, 1969) were taken very seriously. For example, the authorial Preface to the second edition of The Uniting of Europe (Haas, 1968) worked through intergovernmentalist objections and provided a clear statement of neofunctionalist propositions. These in turn reflected the significant work done within the neofunctionalist circle on the importance of background conditions (including societal pluralism) as variables to explain both the initiation and the embedding of regional integration. One of the potential consequences of posing the theoretical past in terms of the titanic clash between two grand theories is the likelihood that both will be posed in simplistic, stylized and static terms. Neofunctionalism is often reduced to a set of propositions about the salience of non-state actors and the primacy of the spillover dynamic, which inevitably directs attention away from the neofunctionalists' extensive work on background conditions, societal pluralism prior to and within regional orders, and the significance of knowledge and cognition in the integration process (see Rosamond, 2005; Schmitter, 2004 for summary and discussion).

This raises questions of what neofunctionalism was actually able to achieve in it heyday. It is a commonplace to assume that the theory did little more than uncover (i.e. describe) a series of local dynamics in the European setting and thereby lost any potential for analytical leverage and comparative potential. Yet, it has been argued that neofunctionalism provided effective accounts of how and why integration might not take off or succeed in particular contexts (a theory of disintegration as well as integration - Schmitter, 2004). Indeed Haas and Schmitter (1964) arguably used neofunctionalist premises (although not necessarily those familiar in standard representations) to successfully predict the failure of Latin American integration. Also, the idea that scholars have only recently begun to think about the EU in political systemic terms must come under scrutiny when the Eastonian-influenced work of Leon Lindberg (1965, 1966, 1967: Lindberg and Scheingold, 1970) began to take shape some 40 years ago.

Intergovernmentalism too suffers from caricature. One of the first articles in EUP announced that '[D]espite some refinements, European integration theory still 
revolves around the debate between neorealism and neofunctionalism' (Schmidt, 2000: 39, emphasis added). The bottling of Moravcsik (and for that matter Hoffmann before him) as 'neorealist' helps to discursively construct the classical terms of engagement in EU studies as hopelessly entrapped in an unproductive IR problematic. In so doing, it also misunderstands both (a) the nuances of Hoffmann's intergovernmentalism (about which Hoffmann, 1989, 1995 has written in some detail) and (b) the important neo-liberal institutionalist turn in IR that spawned Moravcsik's liberal intergovernmentalist work on European integration. Neoliberal institutionalism has stood for at least decade and a half as the principal rival to neorealist IR in the US debate. As indicted already, Moravcsik's work is as indebted to the standard (American) political science norms of the 1990s as Haas's was to those of the 1960s. And, while the full range of intellectual technologies (formal modelling, statistical and mathematical techniques etc) may have changed, the basic precepts of mainstream political science appear to be rather more static (Kaiser, 1965; de Vree, 1972).

Interestingly in his last essay on European integration Ernst Haas (2004) undertook a rare exercise by attempting re-read neofunctionalism through contemporary lenses. This thought experiment classified neofunctionalist theory as epistemologically 'soft rationalist' and via the elaboration of a 'pragmatic constructivist' ontology, sought to show how a revised form of neofunctionalism could enter into dialogue with some of the softer variants of constructivism and sociological institutionalism. For the most part, complex evolving theoretical movements like neofunctionalism (c1958-1976) are not subject to the kind of scrutiny that would allow such contemporary parallels to be made. While statements of the present acquis academique often follow from honest attempts to develop analytical leverage and avoid various sui generis traps, they might contribute to a situation where the analytical potential of neofunctionalism (revised or otherwise) is never properly investigated. And because the integration theory/neofunctionalism project is associated with a misconceived to develop a predictive science of regional integration studies out of inductive work on the European case, a failure to reinvestigate the credentials of the theory might act as a potential block on the study of European integration re-entering the area of comparative studies of regional orders (see Warleigh, chapter 29 of this volume). It is not simply the case that neofunctionalism was influenced by the interaction of 
'external' and 'internal' drivers of the field during its period of pre-eminence. The way in which neofunctionalism - and integration theory more generally - is placed within disciplinary histories of EU studies is influenced by the same factors.

\section{Conclusions}

This chapter has sought to show that the way in which we construe the evolution of scholarly engagement with EU politics is a far from banal exercise. Indeed as a dynamic field characterised by vibrant debate over epistemology, theory and method, it is perhaps a sign of health that the past is so frequently constructed as a series of propositions that carry implications for the present. There are clearly many conceptions of what constitutes 'scientific progress' in EU studies. That said, there are some dangers of buying into such classifications without critical engagement. Claims about history are claims about the present and, as such, may well carry within them logics of 'necessity' and 'appropriateness'. These in turn (consciously or unconsciously) shape the parameters of possible enquiry in ways that might be consistent with the 'mainstreaming' ideal type outlined above. But there is also an interesting yet under-researched relationship between the object of study (EU politics) and the way we as scholars seek to interpret, analyse and describe it. As such, it is important to recognise the dynamic qualities of fields like EU studies, not simply in terms of evolution and change, but also in terms of how the ways we understand EU politics connect with and feed back into our broader social scientific preoccupations. There are also pedagogical issues here because the way in which we conceptualise the field's history is intimately connected to how we describe the field's present in terms of disciplinary location, key puzzles and relevant literature. Unless it is our intention to devise a completely 'mainstreamed' EU studies that obeys the dictums of Kuhnian 'normal science', then one interesting way of keeping the vibrant debate about the nature of the field open would be to throw the question back at our students.

\section{References}

Anderson, Jeffrey J. (1995) 'The State of the (European) Union: From the Singular Event to General Theories', World Politics 47(3), pp.441-465.

Andreatta, Filippo (2005) 'Theory and the European Union's International Relations', in Hill, Christopher and Smith, Michael (eds) International Relations and the European Union,

Oxford: Oxford University Press, pp. 18-38. 
Appadurai, Arjun (1996) Modernity at Large: Cultural Dimensions of Globalization, Minneapolis, University of Minnesota Press

Bailey, David J. (2006) 'Governance or the crisis of governmentality? Applying critical state theory at the European level', Journal of European Public Policy 13(1), pp. 16-33.

Bates, Robert E. (1996) 'Letter from the President: Area Studies and the Discipline', APSACP Newsletter of the APSA Organized Section in Comparative Politics 7(1), pp.1-2.

Bates, Robert, Greif, Avner, Levi, Margaret, Rosenthal, Jean-Laurent and Weingast, Barry (1998) Analytical Narratives, Princeton, NJ: Princeton University Press.

Begg, Iain and Peterson, John (1999) 'Editorial', Journal of Common Market Studies 37(1), pp. 1-12.

Bulmer, Simon and Scott, Andrew (1991) 'Editorial', Journal of Common Market Studies 29(6), pp. 573-574.

Börzel, Tanja (ed.) The Disparity of European Integration: Revisiting Neofunctionalism in Honour of Ernst B. Haas London: Routledge.

Calhoun, Craig (2003) 'European Studies: Always Already There and Still in Formation', Comparative European Politics 1(1), pp. 5-20.

Caporaso, James A. (1999) 'Toward a Normal Science of Regional Integration', Journal of European Public Policy 6(1), pp. 160-164.

Checkel, Jeffrey T. (2001a) 'From meta- to substantive theory? Social constructivism and the study of Europe', European Union Politics 2(2), pp. 219-228.

Checkel, Jeffrey T. (2001b) 'Constructivism and Integration Theory: Crash Landing or Safe Arrival?', European Union Politics 2(2), pp. 240-245.

Christiansen, Thomas and Jørgensen, Knud Erik (1999) 'The Amsterdam Process: A Structurationist Perspective on EU Treaty Making', European Integration Online Papers 3(10) http://eiop.or.at/eiop/texte/1999-001a.htm

Christiansen, Thomas, Jørgensen, Knud Erik and Wiener, Antje (2001) 'Introduction', in Christiansen, Thomas, Jørgensen, Knud Erik and Wiener, Antje (eds) The Social Construction of Europe, London: Sage, pp. 1-19.

Cini, Michelle (2006) 'The "State of the Art" in EU Studies: From Politics to Interdisciplinarity (and Back Again?)', Politics 26(1), pp.38-46.

Cohn, Jonathan (1999) 'Irrational Exuberance. When Did Political Science Forget About Politics?', The New Republic, 25 October

Collini, Stefan, Winch, Donald and Burrow, J.W (1983) That noble science of politics: a study in nineteenth century intellectual history, Cambridge: Cambridge University Press.

Diez, Thomas and Wiener, Antje (2004) 'Introducing the Mosaic of Integration Theory', in Wiener, A. and Diez, T. (eds) European Integration Theory, Oxford: Oxford University Press, pp.1-21. 
Dinan, Desmond (2006) 'The Historiography of European Integration', in Dinan, Desmond (ed.) Origins and Evolution of the European Union, Oxford: Oxford University Press, 297324.

Dowding, Keith (2000) 'Institutional Research on the European Union: A Critical Review', European Union Politics 1(1), pp. 125-144.

Dyrzek, John S. (2002) ' A Pox on Perestroika, a Hex on Hegemony: Toward a Critical Political Science', Annual Conference of the American Political Science Association, Boston, MA, 29 August-1 September.

Fearon, James and Wendt, Alexander (2002) 'Rationalism v Constructivism: A Skeptical View', Carlsnaes, Risse, Thomas and Simmons, Beth A. (eds) Handbook of International Relations, London: Sage, pp. 52-72.

Fuller, Steve (2003) Kuhn vs. Popper: the Struggle for the Soul of Science, London: Icon Books.

Geyer, Robert (2003) 'European Integration, the Problem of Complexity and the Revision of Theory', Journal of Common Market Studies 41(1), pp. 15-35.

Gunnell, John G. (2005) 'Political Science on the Cusp: Recovering a Discipline's Past', American Political Science Review 99(4), pp. 597-609.

Haas, Ernst B. (1968) The Uniting of Europe: Political, Social and Economic Forces, 1950$1957,2^{\text {nd }}$ edn, Stanford, CA: Stanford University Press.

Haas, Ernst B. (1975) The Obsolescence of Regional Integration Theory, working paper, Berkeley: Institute of International Studies.

Haas, Ernst B. (1976) 'Turbulent Fields and the Study of Regional Integration, International Organization 30(2), pp. 173-212.

Haas, Ernst B. (2001) 'Does constructivism subsume neofunctionalism?', in Christiansen, Thomas, Jørgensen, Knud Erik and Wiener, Antje (eds) The Social Construction of Europe, London: Sage, pp. 22-31.

Haas, Ernst B. (2004) 'Introduction: institutionalism or constructivism?', in The Uniting of Europe: Political, Social and Economic Forces, 1950-1957, $3^{\text {rd }}$ edn, Notre Dame, IN: University of Notre Dame Press.

Haas, Ernst B. and Schmitter, Philippe C. (1964) 'Economics and differential patterns of integration: projections about unity in Latin America', International Organization 18(4), pp. 705-737.

Hancock, M. Donald (1999) 'The Study of Europe in the United States: The Makins Report', ECSA Review 12(1) http://ecsa.org/makinsforum.htm

Hansen, Roger D. (1969) 'European Integration: Reflections on a Decade of Theoretical Efforts', World Politics 21(2), pp. 242-271.

Hay, Colin (2002) Political Analysis: A Critical Introduction, Basingstoke: Palgrave.

Hix, Simon (1994) 'The Study of the European Community: the Challenge to Comparative Politics, West European Politics 17(1), pp.1-30. 
Hix, Simon (1996) 'IR, CP and the EU: A Rejoinder to Hurrell and Menon', West European Politics 19(4), pp. 802-804.

Hix, Simon (1998) 'The Study of the European Union II: The "New Governance" Agenda and Its Rival', Journal of European Public Policy 5(1), pp.38-65.

Hix, Simon (2005) The Political System of the European Union, $2^{\text {nd }}$ edn, Basingstoke and New York: Palgrave Macmillan.

Hoffmann, Stanley (1966) 'Obstinate or Obsolete? The Fate of the Nation-State and the Case of Western Europe', Daedalus 95(3), pp. 862-915.

Hoffmann, Stanley (1989) 'A retrospective', in Kruzel, J. and Rosenau, James N. (eds) Journeys Through World Politics: Autobiographical Reflections of Thirty-four Academic Travelers, Lexington, MA: Lexington Books.

Hoffmann, Stanley (1995) The European Sisyphus: Essays on Europe, 1964-1994 Boulder, CO: Westview.

Hooghe, Liesbet (2001) The European Commission and the Integration of Europe: Images of Governance, Cambridge: Cambridge University Press.

Hooghe, Liesbet and Marks, Gary (2003) 'Unravelling the Central State, but How? Types of Multi-level Governance', American Political Science Review 97(2), pp. 233-243.

Inglehart, Ronald (1967) 'An End to European Integration', American Political Science Review 61(1), pp. 91-106.

Johnson, Chalmers (1997) 'Preconception vs. Observation, or the Contributions of Rational Choice and Area Studies to Contemporary Political Science', PS: Political Science and Politics, June, pp.170-174.

Jupille, Joseph (2006) 'Knowing Europe: metatheory and methodology in European Union studies', in Cini, M. and Bourne, A.K. (eds) Palgrave Advances in European Union Studies, Basingstoke: Palgrave Macmillan, pp.209-233.

Jupille, Joseph and Caporaso, James A. (1999) 'Institutionalism and the European Union: Beyond Internationalism and Comparative Politics', Annual Review of Political Science 2, pp. 429-444.

Jørgensen, Knud Erik (2004) 'European Foreign Policy: Conceptualising the Domain', in Carlsnaes, Walter, Sjursen, Helene and White, Brian (eds) Contemporary European Foreign Policy, London: Sage, pp. 32-56.

Kaiser, Karl (1965) 'L'Europe des Savants: European Integration and the Social Sciences', Journal of Common Market Studies 4(1), pp. 36-47.

Katzenstein, Peter, Keohane, Robert O. and Krasner, Stephen (1998) 'International Organization and the Study of World Politics', International Organization 52(4), pp.645-685.

Keeler, John S. (2005) 'Mapping EU Studies: The Evolution from Boutique to Boom Field 1960-2001', Journal of Common Market Studies 43(3), pp. 551-582.

Keohane, Robert O. (1988) 'International Institutions: Two Traditions', International Studies Quarterly 32(4), pp. 379-396. 
van Kersbergen, Kees and van Waarden, Frans (2004) "'Governance" as a bridge between disciplines: cross disciplinary inspiration regarding shifts in governance and problems of governability, accountability and legitimacy', European Journal of Political Research 43(2), pp. 143-171.

King, Gary, Keohane, Robert O. and Verba, Sidney (1994) Designing Social Inquiry: Scientific Inference in Quantitative Research, Princeton, NJ: Princeton University Press

Kitzinger, Uwe (1962a) 'Editorial', Journal of Common Market Studies 1(1), pp. v-vi.

Kitzinger, Uwe (1962b) 'The state of the literature in 1960', Journal of Common Market Studies 1(2), pp.187-193.

Kreisler, Harvey (2000) 'Science and progress in international relations: conversation with Ernst B. Haas', October 30, http://globetrotter.berkeley.edu/people/Haas/haas-con0.html (accessed 19 October 2004).

Kuhn, Thomas (1996) [1962] The Structure of Scientific Revolutions, Chicago: University of Chicago Press.

Lieshout, Robert H., Segers, Matthieu L.L. and van der Vleuten, Anna M. (2004) De Gaulle, Moravcsik and The Choice for Europe', Journal of Cold War Studies 6(4), pp. 89-139.

Lindberg, Leon N. (1965) 'Decision-Making and Integration in the European Community', International Organization 19(1), pp. 56-80.

Lindberg, Leon N. (1966) 'Integration as a Source of Stress on the European Community System', International Organization 20(2), pp. 233-266.

Lindberg, Leon N. (1967) 'The European Community as a Political System: Notes Toward the Construction of a Model', Journal of Common Market Studies 5(4), pp. 344-388..

Lindberg, Leon N. and Scheingold, Stuart A. (1970) Europe's Would-Be Polity: Patterns of Change in the European Community, Englewood Cliffs, NJ: Prentice Hall.

Lindberg, Leon N. and Scheingold, Stuart A. (eds) (1971) Regional Integration: Theory and Research, Cambridge, MA: Harvard University Press

Lubomudrov, Andrei Y. (2002) 'Perestroika, Epistemology , and Discipline: Redefinitions of a Political Science', Portland State University, mimeo.

Lustick, Ian S. (1997) 'The Disciplines of Political Science: Studying the Culture of Rational Choice as a Case in Point', PS: Political Science and Politics, June, pp.175-179.

Mancias. Peter (1987) A History and Philosophy of the Social Sciences, Oxford: Blackwell.

Manners, Ian (2003) 'Europaian Studies', Journal of Contemporary European Studies 11(1), pp. 67-83.

Marks, Gary, Hooghe, Liesbet and Blank, Kermit (1996) 'European Integration from the 1980s: State-Centric v. Multi-level Governance, Journal of Common Market Studies 34(3), pp.341-378. 
Marks, Gary, Nielsen, François., Ray, Leonard and Salk, Jane (1996) 'Competencies, Cracks and Conflicts: Regional Mobilization in the European Union', in Marks Gary, Scharpf, Fritz W., Schmitter, Philippe C., Steeck, Wolfgang Governance in the European Union, London, Sage, pp. 40-63.

Mattli, Walter (1999) The Logic of Regional Integration: Europe and Beyond, Cambridge: Cambridge University Press.

McLean, Iain (2003) 'Two Analytic Narratives about the History of the EU', European Union Politics 4(4), pp.499-506.

Mearsheimer, John J. (2001) 'Methodological Parochialism vs. Methodological Pluralism', Annual Conference of the American Political Science Association, San Francisco, CA, 31 August.

Milner, Helen V. (1998) 'Rationalizing Politics: The Emerging Synthesis of International, American and Comparative Politics', International Organization 52(4), pp.759-786.

Milward, Alan S. (1992) The European Rescue of the Nation-State, London: Routledge.

Milward, Alan S. and Sørensen, Vibeke (1993) 'Interdependence or Integration? A National Choice', in Milward, Alan S. et al The Frontier of National Sovereignty: History and Theory 1945-1992, London: Routledge, pp. 1-32.

Moravcsik, Andrew (1997) 'Does the European Union represent an n of 1? ECSA Review 10(3), http://www.eustudies.org/N1debate.htm (accessed 15 March 2006)

Moravcsik, Andrew (1998) The Choice for Europe: Social Purpose and State Power from Messina to Maastricht, Ithaca, NY: Cornell University Press.

Moravcsik, Andrew (1999a) 'The Choice for Europe - Current Commentary and Future Research; A Response to James Caporaso, Fritz Scharpf and Helen Wallace', Journal of European Public Policy 6(1), pp. 168-179.

Moravcsik, Andrew (1999b) 'The Future of European Integration Studies: Social Theory or Social Science?', Millennium: Journal of International Studies 28(2), pp. 371-391

Moravcsik, Andrew (2001a) 'Bringing Constructivist Integration Theory Out of the Clouds: Has it Landed Yet?', European Union Politics 2(2), pp.226-240.

Moravcsik, Andrew (2001b) 'Constructivism and European Integration: A Critique', in Christiansen, T., Jørgensen, K.E. and Wiener, A. (eds) The Social Construction of Europe, London: Sage, pp. 176-188.

Moravcsik, Andrew (2005) 'The European Constitutional Compromise and the neofunctionalist legacy', Journal of European Public Policy 12(2), pp. 349-386.

Murphy, Craig N. and Nelson, Douglas, R. (2001) 'International political economy: a tale of two heterodoxies', British Journal of Politics and International Relations 3(3), pp.393-412.

Murray, Alastair J.H. (1998) Reconstructing Realism: Between Power 349-386Politics and Cosmopolitan Ethics, Edinburgh: Edinburgh University Press

Pahre, Robert (2005) 'Formal Theory and Case-Study Methods in EU Studies', European Union Politics 6(1), pp. 113-143. 
Paterson, William.E. and Rollo, James (2004) 'Editorial', Journal of Common Market Studies 42(1), pp.1-4.

Pollack, Mark A. (2001) 'International Relations Theory and European Integration', Journal of Common Market Studies 39(2), pp. 221-244.

Pollack, Mark A. (2005a) 'Theorizing EU Policy-Making', in Wallace, Helen, Wallace, William and Pollack, Mark A. (eds) Policy-Making in the European Union, $5^{\text {th }}$ edn, Oxford: Oxford University Press, 13-48.

Pollack, Mark A. (2005b) 'Theorizing the European Union: International Organization, Domestic Polity or Experiment in New Governance?', Annual Review of Political Science 8, pp. 357-398.

Puchala, Donald M. (1972) 'Of Blind Men, Elephants and International Integration', Journal of Common Market Studies 10(3), pp. 267-284.

Richardson, Jeremy and Lindley, Robert (1994) 'Editorial', Journal of European Public Policy 1(1), pp. 1-7.

Rosamond, Ben (2000) Theories of European Integration, Basingstoke and New York: Macmillan and St. Martin's Press.

Rosamond, Ben (2005) 'The uniting of Europe and the foundation of EU studies: revisiting the neofunctionalism of Ernst B. Haas', Journal of European Public Policy 12(2), pp.237254.

Rosenthal, Glenda G. (1999) 'The Study of Europe in the United States: the Makins Report', ECSA Review 12(1) http://ecsa.org/makinsforum.htm

Ruggie, John G. (1993) 'Territoriality and Beyond: Problematizing Modernity in International Relations', International Organization 47(1), pp.139-174.

Ruggie, John J., Katzenstein, Peter J., Keohane, Robert O. and Schmitter, Philippe C. (2005) 'Transformations in world politics: the intellectual contributions of Ernst B. Haas', Annual Review of Political Science 8, pp. 271-296

Sandholtz, Wayne and Stone Sweet, Alec (eds) (1998) European Integration and Supranational Governance, Oxford: Oxford University Press.

Schimmelfennig, Frank (2004) 'Liberal Intergovernmentalism', in Wiener, Antje and Diez, Thomas (eds) European Integration Theory, Oxford: Oxford University Press, pp. 75-94.

Schmidt, Brian C. (1998) The Political Discourse of Anarchy: a Disciplinary History of International Relations Albany, NY: SUNY Press

Schmidt, Brian C. (2002) 'On the History and Historiography of International Relations', in Carlsnaes, Walter, Risse, Thomas and Simmons, Beth A. (eds) Handbook of International Relations, London: Sage, 2002, pp.3-22.

Schmidt, Suzanne K. (2000) 'Only an Agenda Setter? The European Commission's Power Over the Council of Ministers', European Union Politics 1(1), pp. 37-62. 
Schmitter, Philippe C. (2004) 'Neo-neo-functionalism?', in Wiener, Antje and Diez, Thomas (eds) European Integration Theory, Oxford: Oxford University Press, pp. 45-74.

Schneider, Gerald, Gabel, Matthew and Hix, Simon (2000) 'European Union Politics Editorial Statement', European Union Politics 1(1), pp. 5-8.

Schneider, Gerald and Aspinwall, Mark (2001) 'Moving Beyond Outworn Debates: a New Institutionalist Research Agenda', in Aspinwall, Mark and Schneider, Gerald (eds) The Rules of Integration: Institutionalist Approaches to the Study of Europe, Manchester: Manchester University Press, pp. 177-187.

Shaw, Jo and More, Gillian (eds) (1995) New Legal Dynamics of European Union, Oxford: Clarendon Press.

Smith, Steve (2000a) 'International theory and European integration', in Kelstrup, Morten and Williams, Michael C. (eds) International Relations Theory and the Politics of European Integration: Power, Security and Community, London: Routledge, pp.33-56.

Smith, Steve (2000b) 'The discipline of international relations: still an American social science?', British Journal of Politics and International Relations 2(3), pp.374-402.

Smith, Steve (2003) 'Singing our world into existence: international relations theory and September 11', International Studies Quarterly. 48(3), pp. 499-415.

Tsoukalis, Loukas (1980) 'Editorial', Journal of Common Market Studies 18(3), pp.215-216.

Verdun, Amy (2003) 'An American/European Divide in European Integration Studies:

Bridging the Gap with International Political Economy (IPE)'. In Jones, Erik and Verdun, Amy (eds) The Political Economy of European Integration: Theory and Analysis, London: Routledge, pp.11-38.

De Vree, Johan K. (1972) Political Integration: The Formation of Theory and its Problems, The Hague: Mouton.

Wagner, Peter, Wittrock, Björn and Whitley, Richard (1991) (eds) Discourses on Society: The Shaping of the Social Scientific Disciplines, Dordnecht: Kluwer.

Wallace, Helen (2000) 'Studying Contemporary Europe'. British Journal of Politics and International Relations, Vol. 2, No. 1, pp. 95-113.

Wallace, Helen (2002) 'Europeanisation and globalisation: complementary or contradictory trends?', in Breslin, Shaun, Hughes, Christopher, Phillips, Nicola and Rosamond, Ben (eds) New Regionalisms in the Global Political Economy: Theories and Cases, London: Routledge. pp. 137-149.

Webb, Carole (1983) 'Theoretical Prospects and Problems', in Wallace, Helen, Wallace, William and Webb, Carole (eds) Policy-Making in the European Community, second edition, Chichester: John Wiley and Sons, pp. 1-41.

Weiler, Joseph H.H. (1991) 'The Transformation of Europe', Yale Law Journal 100(8), pp. 2405-2483.

Wendt, Alexander (1999) Social Theory of International Politics, Cambridge University Press. 
Wendt, Alexander (2001) 'Driving with the Rearview Mirror: On the Rational Science of Institutional Design', International Organization 55(4), pp.1019-1049.

Wessels, Wolfgang (2006) 'Cleavages, controversies and convergence in European Union studies', in Cini, Michelle and Bourne, Angela K. (eds) Palgrave Advances in European Union Studies, Basingstoke: Palgrave Macmillan, pp. 233-246.

Wiener, Antje and Diez, Thomas (2004) 'Taking Stock of Integration Theory', in Wiener, Antje and Diez, Thomas (eds) European Integration Theory, Oxford: Oxford University Press, pp. 237-248.

Williams, Michael C. (2005)The Realist Tradition and the Limits of International Relations, Cambridge: Cambridge University Press.

White, Brian (2001) Understanding European Foreign Policy, Basingstoke: Palgrave.

White, Jonathan P.J. (2003) 'Theory Guiding Practice: the Neofunctionalists and the Hallstein EEC Commission', Journal of European Integration History', Journal of European Integration History 9(1), pp. 111-131.

Whitley, Richard (1984) The Intellectual and Social Organization of the Sciences Oxford: Clarendon Press

Wincott, Daniel (1995) 'Institutional interaction and European integration: towards and everyday critique of liberal intergovernmentalism', Journal of Common Market Studies 33(4), pp.597-609.

Wæver, Ole (1998) 'The Sociology of a Not So International Discipline: American and European Developments in International Relations'. International Organization, 52(4), pp. 687-727.

Wæver, Ole (2003) 'The Structure of the IR Discipline: A Proto-Comparative Analysis', Annual Convention of the International Studies Association, Portland, OR, 25 February - 1 March. 